Int. J. Dev. Biol. 62: 127-136 (2018)

https://doi.org/10.1387/ijdb.170312cm

\title{
Chick muscle development
}

\author{
MARTIN SCAAL ${ }^{1}$ and CHRISTOPHE MARCELLE*,2,3
}

${ }^{1}$ Institute of Anatomy II, University of Cologne, Cologne, Germany, ${ }^{2}$ Australian Regenerative Medicine Institute (ARMI), Monash University, Clayton, Australia and ${ }^{3}$ Institut NeuroMyoGene (INMG), University Lyon1, France

\begin{abstract}
Striated muscle is the most abundant tissue in the body of vertebrates and it forms, together with the skeleton, the locomotory system required both for movement and the creation of the specific body shape of a species. Research on the embryonic development of muscles has a long tradition both in classical embryology and in molecular developmental biology. While the gene networks regulating muscle development have been discovered mostly in the mouse through genetics, our knowledge on cell lineages, muscle morphogenesis and tissue interactions regulating their formation is to a large extent based on the use of the avian model. This review highlights present knowledge of the development of skeletal muscle in vertebrate embryos. Special focus will be placed on the contributions from chicken and quail embryo model systems.
\end{abstract}

KEY WORDS: somite, satellite cell, myotome, dermomyotome

\section{Somite formation and early patterning}

\section{Morphogenesis}

Somites give rise to all the skeletal muscles of the body, with the exclusion of head muscles, which derive from the unsegmented head mesoderm and prechordal mesoderm (reviewed in (BrandSaberi and Christ, 2000; Christ and Ordahl, 1995). Somites are formed from the yet unsegmented presomitic paraxial mesoderm in a process called somitogenesis, which has been thoroughly investigated in recent years and has been extensively described in a number of excellent reviews (see e.g. Maroto et al., 2012, Hubaud and Pourquie 2014), including the review by Olivier Pourquié in this issue. Within an embryo at a given stage, somites of successive developmental stages coexist, the posterior-most somite (named somite stage I according to Christ and Ordahl, 1995) being the most recently formed.

Once somites bud off from the anterior end of the presomitic mesoderm, they have the shape of a hollow sphere consisting of an epithelial wall surrounding a central cavity, the somitocoel, which contains a loose mesenchyme. The basal pole of all somite cells forms the outer surface of the sphere, whereas the apical side faces the somitocoel. In a few hours, somites undergo major changes. The ventral portion of the somites disaggregates into a ventral mesenchyme, the sclerotome, which gives rise to the vertebral column. The dorsal portion of the somite (i.e. the dermomyotome) remains epithelial. As its name implies, derivatives of the dermomyotome comprise muscles and dermis of the back (reviewed in Scaal and Christ 2004). Lineage studies in mouse and birds have also shown that the dermomyotome contains pre- cursors of brown fat, smooth muscles and endothelia (Atit et al., 2006; Ben-Yair and Kalcheim, 2008).

The somite is also polarized along its antero-posterior (A-P) axis, with neural crest cells entering the rostral half of each somitic sclerotome but avoiding the caudal half. Manipulations of avian segmental plate and somites (rotation, inversion, etc.) showed that while the A-P axis of somites was determined at the time of their formation (Keynes and Stern, 1984) the dorso-ventral (D-V) axis was not, such that $D-V$ rotation and medio-lateral inversion of newly formed somite led to normal sclerotome and muscle development (Aoyama and Asamoto 1988; Ordahl and Le Douarin, 1992; Christ et al., 1992). These studies also highlighted a key concept in early myogenesis, which is that somites receive the signals needed for myogenic differentiation from surrounding tissues. They were followed by a multitude of publications that described the structures acting on somite patterning, namely the neural tube, the surface ectoderm, the notochord, and the lateral plate mesoderm (reviewed in Christ et al., 2007).

\section{Genetic control of sclerotome and dermomyotome differentiation}

Two opposing signals orchestrate the formation of the sclerotome and the dermomyotome. Ventrally, Shh, from the notochord and floor plate of the neural tube triggers the epithelial mesenchyme

Abbreviations used in this paper: $\mathrm{AL}$, anterior border of the dermomyotome; DML, dorso-medialborder of the dermomyotome; EMT, epithelial mesenchyme transition; LPM, lateral plate mesoderm; PL, posterior border of the dermomyotome; TZ, transition zone; VLL, ventro-lateral border of the dermomyotome.

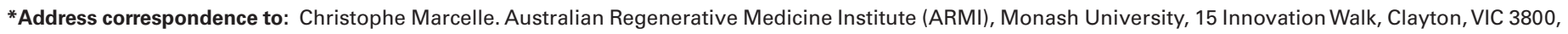
Australia. E-mail: christophe.marcelle@monash.edu
} 
transition (EMT) of the ventral portion of the somite, to form the sclerotome (Fan et al., 1995; Fan and Tessier-Lavigne, 1994; Münsterberg et al., 1995). The sclerotomal cells migrate medially and populate the space around the notochord and neural tube to give rise later to the vertebrae, and laterally to the ribs (reviewed in Christ and Scaal 2004; Scaal 2016). Mesenchymal cells present in the somitocoel participate in the formation of the intervertebral joints and of the intervertebral discs (Huang et al., 1994; Mittapalli et al., 2005).

Counteracting the ventralizing activity of Shh, Wnt6 expressed by the ectoderm overlying the somites triggers and maintains the epithelial organization of the dermomyotome (Schmidt et al., 2004; Linker et al., 2005; Geetha-Loganathan et al., 2006). Wnt, through the canonical, $\beta$-catenin-dependent pathway, acts on the bHLH transcription factor paraxis, necessary for the epithelialisation of somites (Burgess et al., 1996). In paraxis mutant mice, somites are unable to organise themselves into an epithelium, and although the specification of skeletal muscles takes place correctly, the spatial organisation of their muscles is grossly altered (Burgess et al., 1996; Wilson-Rawls et al., 1999). These data indicate that muscle progenitors use the epithelial sheet of the dermomyotome as a scaffold on which they organise to form the myotome.

\section{Epaxial and hypaxial muscle formation in the trunk}

\section{Morphogenesis}

Anatomists divide the vertebrate trunk musculature into epaxial and hypaxial muscles. Epaxial muscles are located dorsal to the ribs in the upper trunk region, and dorsal to the transverse processes of the vertebrae in the rest of the body. They collectively function to both extend the vertebral column and to allow lateral flexion of the body. Hypaxial muscles exert a number of functions in the adult: oblique and transverse muscles form a multi-layered sheet of muscles, which surrounds the abdominal cavity and provides thoracic and pelvic stability. In the rib cage region, intercostal muscles play an important role in breathing. In mammals, breathing movements are largely assisted by the action of the diaphragm (which belongs to the hypaxial muscle group as well). Birds lack a diaphragm and therefore use their intercostal and abdominal muscles to breathe. Regardless of their final location and points of attachment, the epaxial and hypaxial muscles differ in their innervation: the dorsal ramus of the spinal nerves innervates the epaxial muscles while the ventral ramus innervates the hypaxial muscles. Limb and appendicular muscles (the latter also called girdle muscles) are also hypaxial. In higher vertebrates (birds and mammals), girdle muscles have become extremely well developed, inserting as far dorsal as the spinous processes of the vertebrae, while occupying a region spanning the neck and the trunk down to the lumbar region.

Ventrally, they extend as far as the sternum; as a consequence, they cover a large portion of the trunk epaxial and hypaxial muscles.

During embryogenesis, before the future epaxial and hypaxial muscles have formed, the boundary between the two lineages is not obvious. Quail-chick transplants showed that the epaxial myotome is derived from the medial half of the somite whereas the hypaxial myotome arises from the lateral half (Ordahl and Le Douarin, 1992). The medial and lateral somite themselves originate from distinct regions of the primitive streak (and
Hensen's Node) in the gastrulating embryo (Selleck and Stern 1991). Further refinements of these findings came from separate approaches using i) direct labeling of the dorsomedial lip (DML) and ventrolateral lip (VLL) of the dermomyotome with fluorescent dyes (Denetclaw et al., 1997; Denetclaw and Ordahl 2000); ii) retrograde LaacZ labeling in mouse (Eloy-Trinquet and Nicolas 2002b; Eloy-Trinquet and Nicolas 2002a), and iii) electroporation of plasmids coding for fluorescent proteins into the DML and VLL (Gros etal., 2004). Together, these approaches demonstrate that, in amniotes, epaxial and hypaxial muscles mainly arise from the DML and VLL, respectively. A minor contribution to epaxial and hypaxial muscles derive from progenitors present in the anterior and posterior borders of the dermomyotome (AL and PL, respectively; Gros et al., 2004; Kahane et al., 1998a; Denetclaw and Ordahl 2000; see Fig. 1).

During the first stage of muscle morphogenesis, cells arising from the four epithelial borders of the dermomyotome translocate under the dermomyotome where they elongate to reach the anterior and posterior borders of the somite. These differentiated, post-mitotic, mononucleated myocytes form the "primary" myotome. Initially, the DML produces myocytes approximately 13 hours after somite formation, followed hours later by the PL and AL. Lastly, the VLL generate myocytes about a day after somite formation (Gros et al., 2004).

The cellular mechanisms underlying myogenesis at the epithelial border of the dermomyotome have been examined in details. Epithelial cells in the DML can adopt either of two fates: to self-renew and remain in the epithelial structure of the DML or to initiate terminal myogenic differentiation (Denetclaw et al., 2001; Venters et al., 2002; Gros et al., 2004). The cell fate change (myogenic differentiation) is associated with an epithelialmesenchymal transition (EMT) that allows their translocation into the primary myotome (Rios et al., 2011).

The cellular movements occurring at the VLL have not been studied in detail. However, a fundamental functional difference between DML and VLL is that the DML is a stationary source of cells which is located at a rather constant distance of the dorsal neural tube throughout somite development, whereas the VLL is progressively translocating into the mesenchyme of the somatic lateral mesoderm (somatopleure) of the forming body wall as the hypaxial myotome grows (Krück and Scaal 2012). Thus, the VLL appears as a blastema-like, double-layered muscle bud heading towards the ventromedial midline of the embryo, leaving in its path the anlagen of the intercostal and abdominal muscles. The somatopleural mesenchyme, which the hypaxial myotome invades during ventrolateral extension, does not form muscles, but contributes connective tissue, aponeuroses and the sternum to the ventral body wall, thus forming a matrix in which the ingrowing muscles are embedded (Fell 1939, Christ et al., 1974b, 1983; Chevallier 1979).

\section{Genetic control of epaxial muscle formation and organisation}

The genetic networks underlying the activation of myogenesis, notably the four Myogenic Regulatory Factors, MYF5, MYOD, MYOG and MRF4 (Fig. 1) and their relation to the Pax and Six transcription factors, have been exquisitely analyzed by a number of laboratories, using genetic approaches in mice. These important aspects of myogenic differentiation have been covered in many excellent recent reviews (Bryson-Richardson and Currie 
2008; Buckingham and Vincent 2009; Braun and Gautel 2011). We will focus here on the signals and pathways upstream of those molecules.

Because the DML is easily accessible to observation and manipulation, it is where the molecular mechanisms regulating the myogenic differentiation have been most extensively scrutinized. Soon after it was discovered that myogenesis depends upon signals from surrounding tissues (see above), the molecular cues and pathways regulating this process were rapidly identified. One of the first factors identified as key player in the patterning of muscles is BMP4 (Pourquié et al., 1996). BMP4 is expressed in the lateral plate mesoderm (LPM) and in the nascent limb bud and functional analyses showed that it represses myogenesis in the neighboring lateral somite. This has been raised as an argument to explain why myogenesis is initiated medially, away from the LPM (Pourquié et al., 1996). At the same period, a series of studies identified the signals emanating from axial structures that promote myogenesis. They have shown that Wnts expressed in the dorsal neural tube (Wnt1 and Wnt3a) combined to ventrally expressed Shh triggers the myogenic program in somites (Münsterberg et al., 1995; Stern et al., 1995; Tajbakhsh et al., 1998).

Despite a number of publications on the subject, the role of $\mathrm{SHH}$ has remained somewhat obscure, as its effector Gli1-3 displays context-dependent positive and negative regulatory functions on myogenesis, while $\mathrm{SHH}$ itself plays either a proliferative or instructive function in myogenesis (Teillet et al., 1998; Marcelle et al., 1999; Borycki et al., 1999; McDermott et al., 2005).

In contrast, research on Wnt attracted sustained attention over many years. The promoter of the earliest Myogenic Regulatory Factors, Myf5, contains binding sites for the Wnt effector TCF that are necessary for the in vivo expression of Myf5 in the DML (Borello et al., 2006). Moreover, dominant negative and constitutively active forms of TCF and $\beta$-catenin inhibit or activate, respectively, Myf5 expression in somites in vivo (Abu-Elmagd et al., 2010; Gros et al., 2009). This has led to the largely accepted model that myogenesis in somites is under the control of Wnts from the dorsal neural tube acting through a Wnt/ $\beta$ - catenindependent pathway.

This view has been challenged by more recent studies that addressed the question of myogenesis from a different angle, examining the molecular mechanisms regulating the decision of DML cells to undergo myogenesis or self-renew. Given its established role in the regulation of cell fate choice in various contexts, either through lateral inhibition or asymmetric cell division (Lai, 2004; Schweisguth, 2015), the role of the Notch pathway was examined in somites. This showed that Notch signaling is indeed playing a central role in the initiation of myogenesis at the $\mathrm{DML}$, but through a totally unexpected mechanism. Myogenic differentiation is initiated by Delta1-positive neural crest cells migrating from the dorsal neural tube that, in passing, trigger NOTCH signaling and myogenesis (i.e. Myf5 and MyoD expression) in epithelial somite cells. This results in their translocation into a region of the somite, ventro-lateral to the DML, named the Transition Zone (TZ), where they further differentiate (Rios et al., 2011). This mode of signaling, which relies on the cell migration of a tissue (the neural crest) to signal another (the DML) was termed a "kiss and run" mode of signal transduction. Importantly, the mosaic expression of Delta1 in the migrating neural crest cell population ensures that $\mathrm{NOTCH}$ signaling is regularly triggered in selected DML cells, thus explaining the binary cell fate choice necessary

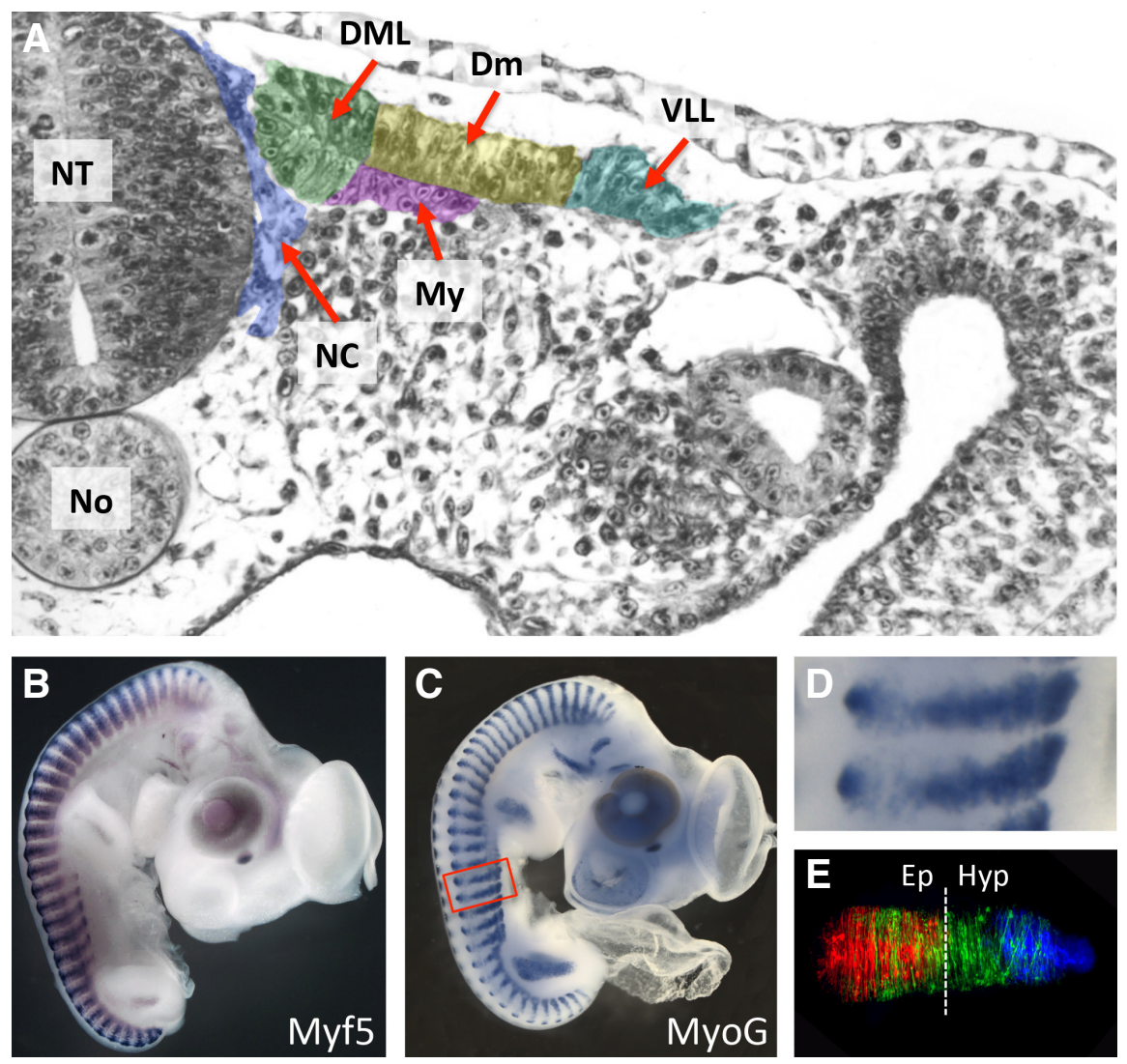

Fig. 1. Early myogenesis in the chicken embryo. (A) Transverse semi-thin section through a two-day old embryo ata somite stage level(VII-IX) where myotome formation is initiated. The various domains of the dermomyotome are pseudo-coloured. Neural crest cells (in blue) en route towards their sites of differentiation migrate in close proximity to the DML. $\mathbf{B}, \mathbf{C})$ Whole mount in situ hybridization (courtesy of Parker Antin at $h$ ttp://geisha.arizona.edu/geisha/) of 4 (B) and 4.5 (C) day old chicken embryos hybridized with Myf5 and MyoG probes identify all muscle masses in the head, trunk and limbs. (D) An elargement of (C). (E) A primary myotome of trunk somites two days after somite formation (at a similar developmental stage to the ones shown in (E)), electroporated with GFP in the four borders of the somite two days earlier. The picture is a composite of four distinct pictures, the contribution of the different borders to myotome formation is shown in different colours. Red: myocytes derived from the $D M L$; green: myocytes derived from the $A L$ and $P L$; blue: myocytes derived from the $V L L$. The vertical line shows the boundary between the epaxial and hypaxial domains of muscles. At this stage of myotome formation, they are about equivalent. The hypaxial domain grows considerably faster than the epaxial domain from that stage of development on Abbreviations: NT, neural tube; No, notochord; DML, dorso- medial lip; Dm, central dermomyotome; My, myotome; VLL, ventro-lateral lip; NC, neural crest; Ep, epaxial; Hy, hypaxial. 
to generate myotomal cells over an extended period of time while self-renewing the progenitor population. Thus NOTCH signaling regulates a binary cell fate choice program, but its mechanism of action is novel and distinct from the previously identified roles of $\mathrm{NOTCH}$ in asymmetric cell division or lateral inhibition.

Within epithelial DML cells, the activation of NOTCH triggers a signaling module (which comprises GSK-3 $\beta$, Snai1 and $\beta$-catenin) that mechanistically links their cell fate change (i.e. the initiation of myogenesis) to an epithelial-mesenchymal transition, allowing their subsequent migration into the myotome (Sieiro et al., 2016). At both ends of the signaling module, $\mathrm{NOTCH}$ and $\beta$-catenin display unexpected functions. The "canonical" role of $\mathrm{NOTCH}$ is to act as a co-transcriptional activator together with Recombining Binding Protein suppressor of Hairless (RBPJ). These data uncover a novel in vivo function of NOTCH that takes place in the cytosol independently of its function in the nucleus. Likewise, it is largely established that $\beta$-catenin participates in adhesion and signaling functions in a mutually exclusive manner (Brembeck et al., 2006; Gavard and Mège, 2012; Nelson and Nusse, 2004). However, this study provides indirect evidence that it is the pool of $\beta$-catenin accumulated at the membrane that activates Myf5 and MyoD expression. Importantly, this study showed that Wnt ligands do not play a role in the activation of Myf5 and MyoD, thereby ruling out a function for Wnts from the dorsal neural tube in early myogenesis. However, it reconciles apparently divergent observations on the respective role of Wnt and Notch signaling as it demonstrated the necessary, but permissive function of $\mathrm{NOTCH}$ in early epaxial myogenesis, while the instructive role is carried out by $\beta$-catenin, but in a WNT ligand-independent way.

Although Wnt1 and 3a expressed by dorsal neural tube likely do not act on early myogenesis, they have a profound role on myotome organization. Using Wnt11 as a specific molecular marker of the DML, it was demonstrated in the chicken embryo that its expression is dependent upon Wnt1 and/or Wnt3a expression in the dorsal neural tube through a Wnt- $\beta$ catenin dependent pathway (Marcelle et al., 1997). Wnt1 and Wnt3a act redundantly in this process (Ikeya and Takada, 1998). Wnt11 itself acts as a directional cue that serves for the polarized elongation of myocytes in the antero-posterior axis of the chick embryo. Wnt11 mediates its action through the evolutionary conserved planar cell polarity (PCP) pathway (Gros et al., 2009). How Wnt1/3a trigger a Wnt- $\beta$ catenin-dependent response in DML cells (i.e. Wnt11 expression) but fail to activate Myf5 expression is unclear. Results obtained in our laboratory indicate that Wnt ligands elicit a low TCF/ $\beta$-catenin transcriptional activity in DML cells that is likely insufficient to trigger myogenesis in this structure, while Notch activation results in a strong TCF/ $\beta$-catenin transcriptional activities that is tightly linked with Myf5 and MyoD expression (Sieiro et al., 2016).

Unexpectedly, Wnt1 and 3a do not form a concentration gradient from the dorsal neural tube that acts at a distance on somites. Rather, Wnt is loaded onto migrating neural crest cells that deliver it to somites (Serralbo and Marcelle, 2014). This is another example that signaling at a distance in vertebrate embryos may significantly rely on cell migration. That neural crest cells are major players in the emergence of epaxial muscles and in their spatial organisation sheds a new light on their role in embryonic development, and it challenges the widely accepted view that the neural crest comprises cells that passively respond to signals from their environment (Le Douarin, 1980). It is also truly remarkable that, during evolution, the independent morphogenic movements of two distinct tissues have become so perfectly coordinated to generate such sophisticated signaling mechanisms.

\section{Genetic control of hypaxial muscle formation}

The signals implicated in the differentiation of the VLL are much less understood. This is in part due to the poor accessibility of the VLL to manipulation, as it sinks deep into the flank of the embryo during development. A second reason is that the differentiation outcomes are more complex than that of the DML. As with the $\mathrm{DML}$, the cells of the VLL can either differentiate to give rise to myocytes or self-renew. However, they also give rise to a multitude of additional cell lineages, such as the smooth muscles of the aorta, lymphatic vessels and vascular endothelial cells (Scaal and Christ 2004). How such a wide array of differentiation routes is molecularly regulated is unclear.

The lateral somite, from which all those lineages derive, is identified by the expression of the bHLH family member Sim1. Its expression results from the antagonistic inducing activities of a medializing signal derived from axial structures and a lateralizing signal, BMP4, secreted by the lateral plate mesoderm (Pourquie et al., 1996). The Sim1-positive domain is apposed, medially, to an En1-positive domain and the balance between both domains depends on Shh signaling from the notochord floor plate complex (Cheng et al., 2004; Martin et al., 2007; Ahmed et al., 2006). As mentioned above, BMP4 delays myogenesis in the hypaxial domain (Pourquié et al., 1996). The formation of the VLL in the hypaxial dermomyotome requires expression of Pax3 downstream of the transcription factors Eya1/2 and Six1/4 (Tremblay et al., 1998; Grifone et al., 2005, 2007). Within the lateral plate mesoderm into which the hypaxial myotomes expand, somatopleural Pitx2 is required for correct myotomal extension, as in Pitx2 mutant mice, myotomal extension is disrupted (Eng et al., 2012).

Endothelia progenitors (angioblasts) are identified in the lateral domain of newly formed somites by the transient expression of the Vascular Endothelial Growth Factor Receptor 2 (VEGFR2; Eichmann et al., 1993; Shalaby et al., 1995; Wilting et al., 1997; Ema et al., 2006). As somites differentiate into sclerotome and dermomyotome, angioblasts have migrated out of somites to colonize the surrounding mesoderm and form vessels. In the limb region, the migration of angioblasts into the limb mesenchyme precedes that of muscle progenitors (Marcelle et al., 2002; Tozer et al., 2007; Yvernogeau et al., 2012). Furthermore, their migration into the limb is prevented in the absence of angioblasts. While it inhibits myogenic differentiation, BMP signaling also promotes endothelial differentiation (Pouget et al., 2006; Ben-Yair and Kalcheim 2008). The role of NOTCH signaling in the VLL is unclear as it was shown to direct an endothelial conversion from non-endothelial somitic cells (Ohata et al., 2009), while other studies suggest that it does not play a role in the initiation of the endothelial fate, but rather in the choice between smooth and skeletal muscle fates (Ben-Yair and Kalcheim 2008).

\section{Embryonic origin of limb and appendicular muscles}

\section{Morphogenesis}

The body plan of tetrapod vertebrates is characterized by the presence of two paired appendages, which have evolved to facilitate locomotion in a terrestrial environment (that later special- 
ized to become wings). Limbs arise from local thickenings of the lateral plate mesoderm. Early embryologists had assumed that the limb muscle cells arise autochthonously, i.e. from the lateral plate mesoderm in the limb buds themselves (e.g. Glücksmann 1934, Saunders 1948, Pinot 1970). Making use of the quail-chick chimera technique, Bodo Christ and others showed in seminal papers that the limb muscle cells originate from the lateral border of the dermomyotomes of somites directly apposed to the growing limb buds (Christ et al., 1974, 1977; Chevallier 1977). While a somitic origin had been postulated in earlier studies (e.g. Fischel 1895, Murray 1928, Grim 1970), this finding was a surprise to most experts of that period.

In the chicken embryo, the wing anlage develops at the level of somites 16-20, while the leg develops at the level of somites 26-32. Using the chick chimera technique and the systematic transplantation of one somite at a time, it was demonstrated that the wing muscles arise from somites 16-21 (Zhi et al., 1996), while leg muscles originate from progenitors present in somites 26-33 (Lance-Jones et al., 1988). Corresponding to their anatomical position, more anterior somites give predominantly rise to radial muscles, and more posterior somites to ulnar muscles, but all muscles receive cells from several, at least 3, different segments, which is reflected in their complex innervation (Zhi et al., 1996; Lance-Jones et al., 1988a, 1988b; Rees et al., 2003).

In both wing and leg anlagen, the muscle precursor cells, initially uniformly distributed within the limb mesenchyme, migrate in two streams of cells under the dorsal and ventral limb bud ectoderm and proliferate to form the dorsal (extensor) and ventral (flexor) pre-muscular masses (Christ et al., 1977). With ongoing growth of the limb, both muscle masses are divided along the proximodistal axis into stylopodial, zeugopodial and autopodial muscle masses, which are subsequently split into individual anatomical muscles separated by connective tissue and linked to the skeleton by tendons (reviewed in Christ and Brand-Saberi 2002). This pattern is not predetermined in the somites, as they mix extensively during myogenic cell migration, but is laid down by the resident limb bud mesenchyme derived from the lateral plate mesoderm (Grim and Wachtler 1991). Likewise, the tendons form independent of the muscle cells and seem to frame the muscle locations autonomously (Kieny and Chevallier 1979, Kardon 1998).

Examination of the origin and development of the perineal muscles in mammals and their avian homologues, the cloacal muscles, uncovered a novel mechanism deployed during formation of limb muscles (Valasek et al., 2005). Myogenic progenitor cells that form the perineal muscles first migrate from the somites into the proximal region of the hind limb. Within the limb bud mesenchyme, nothing distinguishes them from the progenitors that will form the bona fide limb muscles. However, they then migrate back out of the limb mesenchyme and caudo-ventrally to take up their final position in the perineum in mouse or in an analogous position for the cloacal musculature in birds. This morphogenetic process was referred to an "in-out mechanism" mode of muscle formation. A similar mechanism was uncovered during formation of the appendicular muscles of the wing (Valasek et al., 2011) and it therefore likely underlies the formation of appendicular muscles of the pelvic girdle as well.

Limb and girdle muscles are not the only muscles derived from long-range migration of progenitors. Descriptive and experimental studies using lineage-marking techniques in avian (tritiated thymi- dine labelling and quail-chick chimera) have shown that tongue muscles also originate from progenitors emanating from somites 2-6 (Hazelton, 1970; Noden, 1983; Huang et al., 1999). Genetic studies in mouse have shown that the diaphragm, a muscle characteristic to mammals is also derived from anterior somites (Merrell and Kardon, 2013; 2015).

\section{Genetic control of limb muscle formation}

The molecular regulation of limb muscle development has been extensively studied in the last decades, which has been previously covered in a number of excellent reviews on the subject (Christ and Brand- Saberi 2002; Duprez 2002; Vasyutina and Birchmeier 2006; Murphy and Kardon 2011; Deries and Thorsteinsdottir 2016; Huang et al., 2017). In this chapter, we will briefly highlight some milestones in three major steps of limb muscle development, limb muscle cell emigration, differentiation and arrangement into individual muscles.

An early event in limb muscle development is the EMT and emigration of dermomyotomal limb muscle precursor cells, which relies on signals from the lateral plate mesoderm, as grafted limb field mesoderm is able to induce this at non-limb levels (Hayashi and Ozawa 1995). At the core of this process is the Met (Hepatocyte growth factor receptor) signaling pathway. The Met ligand SF/HGF is expressed in the lateral plate mesoderm and its ectopic application leads to the EMT and emigration of muscle precursors at non- limb levels (Brand-Saberi et al., 1996, Heymann et al., 1996). Conversely, the loss of SF/HGF or of Met inhibits limb muscle cell migration and leads to muscle-free limb anlagen (Schmidt et al., 1995; Bladt et al., 1995). After undergoing EMT, the limb muscle precursor cells express the homeobox-transcription factor Lbx1, which is required for the onset of migration (Schäfer and Braun 1999). On their way into the limb bud, expression of Msx1 (Houzelstein et al., 1999), Pax3 (Goulding et al., 1994, Epstein et al., 1996), the Wnt-antagonist Sfrp2 (Anakwe et al., 2003) as well as ongoing interaction with SF/HGF signals in the recipient limb mesenchyme (Dietrich et al.1999; Scaal et al., 1999) are required to keep progenitors motile and guide them to their destination. The migratory routes are guided by attractive and repulsive cues in the limb mesenchyme, mediated by CXCR4/SDF1 and Eph4/Ephrin5 a signaling, respectively (Swartz et al., 2001; Vasyutina et al., 2005). Moreover, extracellular matrix components like fibronectin (Brand-Saberi et al., 1993) and hyaluronic acid (Kosher et al., 1981; Krenn et al., 1991) and appropriate cell-matrix interactions (e.g. via N-cadherin; Brand-Saberi et al., 1996, George-Weinstein et al., 1997) are required for proper myogenic cell migration and pathfinding. The termination of muscle precursor migration coincides with the loss of the SF/HGF-dependent pro-migratory mesenchymal environment at the target sites (Dietrich et al., 1999, Scaal et al., 1999).

Once the muscle precursor cells have reached their destination, they inititate myogenic differentiation. Sonic hedgehog secreted by the mesenchyme in the zone of polarizing activity (ZPA) acts as a survival factor for muscle precursor cells and, in the mouse, has been shown to be necessary for Myf5-dependent muscle differentiation specifically in the ventral muscle masses (Kruger et al., 2001; Hu et al., 2012, Anderson et al., 2012). Moreover, in the chicken, Wnt6, expressed in the ectodermal sheath of the limb buds, has been shown to promote Myf5 dependent myogenesis (Geetha-Loganathan et al., 2005). This ectodermal Wnt signaling 
acts as centripetal patterning mechanism: it promotes myogenesis, but inhibits chondrogenesis in the subectodermal mesenchyme, thus locating the premuscular masses in the peripheral limb mesenchyme as opposed to the chondrogenic mesenchyme in the core of the limb bud (Geetha-Loganathan et al., 2010). In addition to promoting limb myogenesis, Wnt signaling has been shown to regulate the differential development of fast and slow muscle fiber types in limb muscles (Anakwe et al., 2003). FGF signaling from the apical ectodermal ridge (AER) and the underlying distal limb mesenchyme is also required for limb muscle differentiation (Marics et al., 2002; Mok et al., 2014). It is therefore likely that both limb patterning centers, the ZPA and the AER, are involved in regulating limb myogenesis.

In spite of much progress in the last decade, the molecular basis of the formation of individual muscles is still not well understood. The splitting of anatomical muscles from the premuscular masses depends on interactions with the resident limb mesenchyme, which gives rise to the connective tissue of the limb. These cells require the transcription factor Tcf4 to participate in muscle shaping, thus likely forming a pre-pattern of the prospective anatomical muscles (Kardon et al., 2003, Mathew et al., 2011). Moreover, it has been shown that the transcription factors Tbx5 acting via $\mathrm{N}$-cadherin, while $\beta$-Catenin (Hasson et al., 2010) and Hox11 (Swinehart et al., 2013) expressed in the muscular connective tissue are involved in shaping the muscles. Interestingly, the distribution of early blood vessels in the limb bud mesenchyme is involved in determining the anatomical location of muscles by secreting PDGFB at the muscle splitting sites within the prospective connective tissue (Tozer et al., 2007). Muscles themselves are required for the differentiation of tendons. FGF signaling from muscle cells induces collagen synthesis by expression of Egr1 and Egr2 transcripton factors, and expression of tendon markers like scleraxis and tenascin (EdomVovard et al., 2002; Lejard et al., 2011; Havis et al., 2016). Finally, the development of bony tubercles and ridges where tendons attach to the skeleton depends on signals from muscles (Blitz et al., 2013, reviewed in Huang 2017). Thus, development of the locomotory system in limbs, which is integrating muscle, tendon and bone formation, arises from a complex signaling network which is only beginning to be understood (Huang 2017).

\section{The embryonic origin of resident muscle progenitors and satellite cells}

\section{Morphogenesis}

As described above, during early somite differentiation, muscle growth in the trunk is entirely dependent upon the generation of postmitotic myocytes emanating from the four borders of the epithelial dermomyotome that contribute to the growth of the primary myotome (Gros et al., 2004). However, the dermomyotome is a temporary structure that progressively disappears during development (Christ and Ordahl, 1995); thus, this mode of myotome formation cannot account for the continuous and intense growth of muscles observed during embryonic and fetal life. "Resident" muscle progenitors (a term coined by Frédéric Relaix and Margaret Buckingham to design progenitors, which are committed to myogenic differentiation and that are present in the muscle masses during embryonic and fetal life; Relaix et al., 2005) had been identified decades ago in all skeletal muscles of amniote embryos, through their expression of early muscle differentiation markers (e.g. Pax7 or Myf5) or their ability to give rise to muscles in culture (Hauschka, 1974). However, the timing and the process through which they appear within muscles were unknown. In the adult, muscle growth and repair rely on the proliferation and the differentiation of -normally quiescent-adult muscle stem cells, the satellite cells, first identified by Alexander Mauro in frog (Mauro, 1961). Their embryonic origin was controversial: early experiments using the quail chick chimera technique pointed to a somitic origin for satellite cells (Armand et al., 1983). However, more recent studies suggested that a wide variety of tissues including the embryonic dorsal aorta of mouse embryos (DeAngelis, 1999), the bone marrow, (Ferrari et al., 1998; Gussoni et al., 1999) and poorly characterized mesenchymal cells present in muscles (Asakura and Rudnicki, 2002; Polesskaya et al., 2003) can participate in the regeneration of adult muscles. This suggested a model where muscle repair and thus satellite cell development could take place partially or totally independently of somitic myogenesis. To resolve these issues, lineage-tracing of the dermomyotome using a combination of electroporation of fluorescent reporters and the quail-chick chimera technique was performed. This demonstrated that during development, there is a unique source for embryonic and foetal resident muscle progenitors, the central dermomyotome (Fig. 1), and that all satellite cells are derived from that population of resident progenitors (Gros et al.,2005). Using genetic approaches, similar observations were made in the mouse (Kassar-Duchossoy et al., 2005; Relaix et al., 2005).

The morphogenetic mechanism underlying their emergence has been deciphered. It was shown that resident muscle progenitors emerge from the central portion of the dermomyotome when it undergoes an EMT, which occurs in the trunk region in mice at E10.5 and in chicken embryo at E3.5 (Gros et al., 2005, Ben-Yair and Kalcheim, 2005). The de-epithelialization of the dermomyotome is initiated centrally and progresses in all directions throughout the dermomyotome. However, the DML and VLL are protected by Wnt signaling (Linker et al., 2005, Krück and Scaal 2012) from this wave of de-epithelialization for many days of embryonic development, during which they continue to produce myocytes.

A movie of a dermomyotome as it undergoes EMT showed that to enter the primary myotome, resident muscle progenitors directly translocate (they are "parachuted") from the dermomyotome into the myotome. The observation of this process revealed interesting additional features: a cell division preceded the translocation, after which one of the daughter cells entered the myotome, while the other remained in the dermomyotome (Gros et al., 2005)

\section{Genetic control of resident muscle progenitor differentiation}

Since dermal precursors are also derived from the dermomyotome, it is therefore not surprising that the molecular mechanisms that regulate dermis formation regulate muscle progenitor emergence as well. Single cell labeling demonstrated that individual cells within the dermomyotome can adopt one of two fates: either differentiate into a dermal progenitor or into a muscle progenitor (Ben-Yair and Kalcheim 2005). Similar to the situation found in the DML, this is a clear example of a binary cell fate choice taking place in the dermomyotome. In this case, however, evidence for a role of asymmetric cell division in this choice is compelling. Kalcheim's group showed that during the growing phase of the dermomyotome, as cells divide symmetrically, their plane of cell division is mostly parallel to the apico-basal axis of epithelial cells 
(i.e. perpendicular to the plane of the dermomyotome). This results in daughter cells that share similar intracellular components. Focusing on one major player of the adherens junctions in this tissue, $\mathrm{N}$ - cadherin, they observed that during EMT the plane of division shifts to become perpendicular to the apico-basal axis and that this results in the asymmetric distribution of $\mathrm{N}$-cadherin in daughter cells. The over- expression or the down-regulation of $\mathrm{N}$-cadherin drives the differentiation of dermomyotome cells towards a myogenic or dermis fate, respectively (Cinnamon et al., 2006). In search for an upstream molecular event that regulates spindle orientation, they recently uncovered a crucial role for the G-protein regulator LGN, a known regulator of the orientation of cell division and the differential fate acquisition of Drosophila embryonic neuroblasts (Ben-Yair et al., 2011). Since N-cadherin and LGN are ubiquitously expressed throughout the dermomyotome, it is likely that additional cues define the regions/cells that can adopt both fates or not.

Since the EMT of the central dermomyotome is tightly associated with the emergence of resident progenitors, factors that regulate its EMT are of importance to their emergence. As mentioned above, Wnt6 expressed by the ectoderm maintains the epithelial organisation of the dermomyotome. Its activity is counteracted by FGF, expressed by the primary myotome. As the primary myotome grows, it delivers increasing amounts of FGF to the overlying dermomyotome which eventually alters the balance, thus triggering the EMT of the dermomyotome through an ERK/Snail1 pathway (Delfini et al., 2009).

Genetic analyses in mouse have also demonstrated the crucial role that the transcription factors $\mathrm{Pax} 3$ and $\mathrm{Pax} 7$ cooperatively play in the specification of resident muscle progenitors. In mice deficient for both Pax3 and Pax7, all muscle progenitors are absent and muscle growth is consequently arrested. In those mice, the formation of the primary myotome seems unaffected, but resident muscle progenitors either undergo apoptosis, or assume non-myogenic fates (Relaix et al., 2005).

\section{Concluding remarks}

The developing avian embryo has had a long and illustrious career in developmental biology spanning several millennia of observation and research. Over the last hundred years, its amenability to manipulation has allowed the investigation of a diverse range of topics in the field of myogenesis that include tissue morphogenesis, embryonic origin of mesoderm derivatives or the cellular and molecular interactions regulating cell fate decisions. The advent of novel technologies, such as in vivo electroporation, in vivo observation of cell behavior with classical and two photon confocal video- microscopy and the now emerging techniques of transgenesis in quail, open new fields of investigation, until now restricted to more simple systems. This makes the chick embryo one of the most exciting and versatile model to characterize in an amniote environment dynamic developmental processes and there is no doubt that the chicken embryo will maintain its eminent importance in the future research on muscle development.

\section{Acknowledgements}

We thank Laura Galvis for critical reading of the manuscript. This work was supported by grants from the Australian Research Council to C.M. The Australian Regenerative Medicine Institute is supported by grants from the State Government of Victoria and the Australian Government. The NeuroMyoGene Institute is supported by grants from the Associa- tion Française contre les Myopathies (AFM). We dedicate this review to Bodo Christ (1941-2016), a wonderful mentor and colleague, and a major contributor of seminal discoveries in the field.

\section{References}

ABU-ELMAGD, M., ROBSON, L., SWEETMAN, D., HADLEY, J., FRANCIS-WEST, P. and MUNSTERBERG, A. (2010). Wnt/Lef1 signaling acts via Pitx2 to regulate somite myogenesis. Dev Biol 337: 211-219.

AHMED, M.U., CHENG, L. and DIETRICH, S. (2006). Establishment of the epaxialhypaxial boundary in the avian myotome. Dev Dyn 235: 1884-1894.

ANAKWE, K., ROBSON, L., HADLEY, J., BUXTON, P., CHURCH, V., ALLEN, S., HARTMANN, C., HARFE, B., NOHNO, T., BROWN, A.M. et al., (2003). Wnt signalling regulates myogenic differentiation in the developing avian wing. $D e-$ velopment 130: 3503-3514.

ANDERSON, C., WILLIAMS, V.C., MOYON, B., DAUBAS, P., TAJBAKHSH, S., BUCKINGHAM, M.E., SHIROISHI, T., HUGHES, S.M. and BORYCKI, A.G. (2012). Sonic hedgehog acts cell-autonomously on muscle precursor cells to generate limb muscle diversity. Genes Dev 26: 2103-2117.

AOYAMA, H. and ASAMOTO, K. (1988). Determination of somite cells: independence of cell differentiation and morphogenesis. Development 104: 15-28.

ARMAND, O., BOUTINEAU, A.M., MAUGER, A., PAUTOU, M.P. and KIENY, M. (1983). Origin of satellite cells in avian skeletal muscles. Arch Anat Microsc Morphol Exp 72: 163-181.

ASAKURA, A. and RUDNICKI, M.A. (2002). Side population cells from diverse adult tissues are capable of in vitro hematopoietic differentiation. Exp Hematol 30: 1339-1345.

ATIT, R., SGAIER, S.K., MOHAMED, O.A., TAKETO, M.M., DUFORT, D., JOYNER, A.L., NISWANDER, L. and CONLON, R.A. (2006). Beta-catenin activation is necessary and sufficient to specify the dorsal dermal fate in the mouse. Dev Biol 296: 164-176.

BEN-YAIR, R., KAHANE, N. and KALCHEIM, C. (2011). LGN-dependent orientation of cell divisions in the dermomyotome controls lineage segregation into muscle and dermis. Development 138: 4155-4166.

BEN-YAIR, R. and KALCHEIM, C. (2005). Lineage analysis of the avian dermomyotome sheet reveals the existence of single cells with both dermal and muscle progenitor fates. Development 132: 689-701.

BEN-YAIR, R. and KALCHEIM, C. (2008). Notch and bone morphogenetic protein differentially act on dermomyotome cells to generate endothelium, smooth, and striated muscle. J Cell Biol 180: 607-618.

BLADT, F., RIETHMACHER, D., ISENMANN, S., AGUZZI, A. and BIRCHMEIER, C. (1995). Essential role for the c-met receptor in the migration of myogenic precursor cells into the limb bud. Nature 376: 768-771.

BLITZ, E., SHARIR, A., AKIYAMA, H. and ZELZER, E. (2013). Tendon-bone attachment unit is formed modularly by a distinct pool of Scx- and Sox9-positive progenitors. Development 140: 2680-2690.

BORELLO, U., BERARDUCCI, B., MURPHY, P., BAJARD, L., BUFFA, V., PICCOLO, S., BUCKINGHAM, M. and COSSU, G. (2006). The Wnt/beta-catenin pathway regulates Gli-mediated Myf5 expression during somitogenesis. Development 133: 3723-3732.

BORYCKI, A.G., BRUNK, B., TAJBAKHSH, S., BUCKINGHAM, M., CHIANG, C. and EMERSON, C.P., JR. (1999). Sonic hedgehog controls epaxial muscle determination through Myf5 activation. Development 126: 4053-4063.

BRAND-SABERI, B. and CHRIST, B. (2000). Evolution and development of distinct cell lineages derived from somites. Curr Top Dev Biol 48: 1-42.

BRAND-SABERI, B., KRENN, V., GRIM, M. and CHRIST, B. (1993). Differences in the fibronectin-dependence of migrating cell populations. Anat Embryol (Berl) 187: 17-26.

BRAND-SABERI, B., MULLER, T.S., WILTING, J., CHRIST, B. and BIRCHMEIER, C. (1996). Scatter factor/hepatocyte growth factor (SF/HGF) induces emigration of myogenic cells at interlimb level in vivo. Dev Biol 179: 303-308.

BRAUN, T. and GAUTEL, M. (2011). Transcriptional mechanisms regulating skeletal muscle differentiation, growth and homeostasis. Nat Rev Mol CellBiol12:349-361.

BREMBECK, F.H., ROSARIO, M. and BIRCHMEIER, W. (2006). Balancing cell adhesion and Wnt signaling, the key role of beta-catenin. Curr Opin Genet Dev16:51-59. 
BRYSON-RICHARDSON, R.J. and CURRIE, P.D. (2008). The genetics of vertebrate myogenesis. Nat Rev Genet 9: 632-646.

BUCKINGHAM, M. and VINCENT, S.D. (2009). Distinct and dynamic myogenic populations in the vertebrate embryo. Curr Opin Genet Dev 19: 444-453.

BURGESS, R., RAWLS, A., BROWN, D., BRADLEY, A. and OLSON, E.N. (1996). Requirement of the paraxis gene for somite formation and musculoskeletal patterning. Nature 384: 570-573.

CHENG, L., ALVARES, L.E., AHMED, M.U., EL-HANFY, A.S. and DIETRICH, S. (2004). The epaxial-hypaxial subdivision of the avian somite. Dev Biol 274: 348-369.

CHEVALLIER, A. (1979). Role of the somitic mesoderm in the development of the thorax in bird embryos. II. Origin of thoracic and appendicular musculature. $J$ Embryol Exp Morphol 49: 73-88.

CHEVALLIER, A., KIENY, M. and MAUGER, A. (1977). Limb-somite relationship: origin of the limb musculature. J Embryol Exp Morphol 41: 245-258.

CHRIST, B. and BRAND-SABERI, B. (2002). Limb muscle development. Int J Dev Biol 46: 905-914.

CHRIST, B., BRAND-SABERI, B., GRIM, M. and WILTING, J. (1992). Local signalling in dermomyotomal cell type specification. Anat Embryol (Berl) 186: 505-510.

CHRIST, B., HUANG, R. and SCAAL, M. (2004). Formation and differentiation of the avian sclerotome. Anat Embryol (Berl) 208: 333-350.

CHRIST, B., HUANG, R. and SCAAL, M. (2007). Amniote somite derivatives. Dev Dyn 236: 2382-2396.

CHRIST, B., JACOB, H.J. and JACOB, M. (1974). Experimentelle Untersuchungen zur Entwicklung der Brustwand beim Hühnerembryo. Experientia 30: 1449-1451.

CHRIST, B., JACOB, H.J. and JACOB, M. (1974). Über den Ursprung der Flügelmuskulatur. Experientia 30: 1446-1449.

CHRIST, B., JACOB, H.J. and JACOB, M. (1977). Experimental analysis of the origin of the wing musculature in avian embryos. Anat Embryol (Berl) 150: 171-186.

CHRIST, B. and ORDAHL, C.P. (1995). Early stages of chick somite development. Anat Embryol (Berl) 191: 381-396.

CINNAMON, Y., BEN-YAIR, R. and KALCHEIM, C. (2006). Differential effects of $\mathrm{N}$-cadherin-mediated adhesion on the development of myotomal waves. Development 133: 1101-1112.

DE ANGELIS, L., BERGHELLA, L., COLETTA, M., LATTANZI, L., ZANCHI, M., CUSELLA-DE ANGELIS, M.G., PONZETTO, C. and COSSU, G. (1999). Skeletal myogenic progenitors originating from embryonic dorsal aorta coexpress endothelial and myogenic markers and contribute to postnatal muscle growth and regeneration. J Cell Biol 147: 869-878.

DELFINI, M.C., DE LA CELLE, M., GROS, J., SERRALBO, O., MARICS, I., SEUX, M., SCAAL, M. and MARCELLE, C. (2009). The timing of emergence of muscle progenitors is controlled by an FGF/ERK/SNAIL1 pathway. Dev Bio/333:229-237.

DENETCLAW, W.F., JR., BERDOUGO, E., VENTERS, S.J. and ORDAHL, C.P. (2001). Morphogenetic cell movements in the middle region of the dermomyotome dorsomedial lip associated with patterning and growth of the primary epaxial myotome. Development 128: 1745-1755.

DENETCLAW, W.F., JR., CHRIST, B. and ORDAHL, C.P. (1997). Location and growth of epaxial myotome precursor cells. Development 124: 1601-1610.

DENETCLAW, W.F. and ORDAHL, C.P. (2000). The growth of the dermomyotome and formation of early myotome lineages in thoracolumbar somites of chicken embryos. Development 127: 893-905.

DERIES, M. and THORSTEINSDOTTIR, S. (2016). Axial and limb muscle development: dialogue with the neighbourhood. Cell Mol Life Sci 73: 4415-4431.

DIETRICH, S., ABOU-REBYEH, F., BROHMANN, H., BLADT, F., SONNENBERGRIETHMACHER, E., YAMAAI, T., LUMSDEN, A., BRAND-SABERI, B. and BIRCHMEIER, C. (1999). The role of SF/HGF and c-Met in the development of skeletal muscle. Development 126: 1621-1629.

DUPREZ, D. (2002). Signals regulating muscle formation in the limb during embryonic development. Int J Dev Biol 46: 915-925.

EDOM-VOVARD, F., SCHULER, B., BONNIN, M.A., TEILLET, M.A. and DUPREZ, D. (2002). Fgf4 positively regulates scleraxis and tenascin expression in chick limb tendons. Dev Biol 247: 351-66.

EICHMANN, A., MARCELLE, C., BREANT, C. and LE DOUARIN, N.M. (1993). Two molecules related to the VEGF receptor are expressed in early endothelial cells during avian embryonic development. Mech Dev 42: 33-48.
ELOY-TRINQUET, S. and NICOLAS, J.F. (2002). Cell coherence during production of the presomitic mesoderm and somitogenesis in the mouse embryo. Development 129: 3609-3619.

ELOY-TRINQUET, S. and NICOLAS, J.F. (2002). Clonal separation and regionalisation during formation of the medial and lateral myotomes in the mouse embryo. Development 129: 111-122.

EMA, M., YOKOMIZO, T., WAKAMATSU, A., TERUNUMA, T., YAMAMOTO, M. and TAKAHASHI, S. (2006). Primitive erythropoiesis from mesodermal precursors expressing VE-cadherin, PECAM-1, Tie2, endoglin, and CD34 in the mouse embryo. Blood 108: 4018-4024.

ENG, D., MA, H.Y., XU, J., SHIH, H.P., GROSS, M.K. and KIOUSSI, C. (2012). Loss of abdominal muscle in Pitx2 mutants associated with altered axial specification of lateral plate mesoderm. PLoS One 7: e42228.

EPSTEIN, J.A., SHAPIRO, D.N., CHENG, J., LAM, P.Y. and MAAS, R.L. (1996). Pax3 modulates expression of the c-Met receptor during limb muscle development. Proc Natl Acad Sci USA 93: 4213-4218.

FAN, C.M., PORTER, J.A., CHIANG, C., CHANG, D.T., BEACHY, P.A. and TESSIERLAVIGNE, M. (1995). Long- range sclerotome induction by sonic hedgehog: direct role of the amino-terminal cleavage product and modulation by the cyclic AMP signaling pathway. Cell 81: 457-465.

FAN, C.M. and TESSIER-LAVIGNE, M. (1994). Patterning of mammalian somites by surface ectoderm and notochord: evidence for sclerotome induction by a hedgehog homolog. Cell 79: 1175-1186.

FELL, H.B. (1939). On the origin and developmental mechanics of the avian sternum Philos Trans $R$ Soc Lond [Biol] 229: 407-464.

FERRARI, G., CUSELLA-DE ANGELIS, G., COLETTA, M., PAOLUCCI, E., STORNAIUOLO, A., COSSU, G. and MAVILIO, F. (1998). Muscle regeneration by bone marrow-derived myogenic progenitors. Science 279: 1528-1530.

FISCHEL, A. (1895). Zur Entwicklung der ventralen Rumpf- und Extremitätenmuskulatur der Vögel und Säugetiere. Morphol. Jb. 23: 544-561.

GAVARD, J. and MEGE, R.M. (2005). Once upon a time there was beta-catenin in cadherin-mediated signalling. Biol Cell 97: 921-926.

GEETHA-LOGANATHAN, P., NIMMAGADDA, S., CHRIST, B., HUANG, R. and SCAAL, M. (2010). Ectodermal Wnt6 is an early negative regulator of limb chondrogenesis in the chicken embryo. BMC Dev Biol 10: 32.

GEETHA-LOGANATHAN, P., NIMMAGAdDA, S., HUANG, R., CHRIST, B. and SCAAL, M. (2006). Regulation of ectodermal Wnt6 expression by the neural tube is transduced by dermomyotomal Wnt11: a mechanism of dermomyotomal lip sustainment. Development 133: 2897-2904.

GEETHA-LOGANATHAN, P., NIMMAGADDA, S., PROLS, F., PATEL, K., SCAAL, M., HUANG, R. and CHRIST, B. (2005). Ectodermal Wnt-6 promotes Myf5-dependent avian limb myogenesis. Dev Biol 288: 221-233.

GEORGE-WEINSTEIN, M., GERHART, J., BLITZ, J., SIMAK, E. and KNUDSEN, K.A. (1997). N-cadherin promotes the commitment and differentiation of skeletal muscle precursor cells. Dev Biol 185: 14-24.

GLÜCKSMANN, A. (1934). Über die Entwicklung der Amniotenextremitäten und ihre Homologie mit den Flossen. Z Anat. Entwicklungsgesch. 102: 498.

GOULDING, M., LUMSDEN, A. and PAQUETTE, A.J. (1994). Regulation of Pax-3 expression in the dermomyotome and its role in muscle development. Development 120: 957-971.

GRIFONE, R., DEMIGNON, J., GIORDANI, J., NIRO, C., SOUIL, E., BERTIN, F., LACLEF, C., XU, P.X. and MAIRE, P. (2007). Eya1 and Eya2 proteins are required for hypaxial somitic myogenesis in the mouse embryo. Dev Biol 302: 602-616.

GRIFONE, R., DEMIGNON, J., HOUBRON, C., SOUIL, E., NIRO, C., SELLER, M.J., HAMARD, G. and MAIRE, P. (2005). Six1 and Six4 homeoproteins are required for $\mathrm{Pax} 3$ and Mrf expression during myogenesis in the mouse embryo. Development 132: 2235-2249.

GRIM, M. (1970). Differentiation of myoblasts and the relationship between somites and the wing bud of the chick embryo. Z Anat Entwicklungsgesch 132: 260-271.

GRIM, M. and WACHTLER, F. (1991). Muscle morphogenesis in the absence of myogenic cells. Anat Embryol (Berl) 183: 67-70.

GROS, J., SCAAL, M. and MARCELLE, C. (2004). Atwo-step mechanism for myotome formation in chick. Dev Cell 6: 875-882.

GROS, J., SERRALBO, O. and MARCELLE, C. (2009). WNT11 acts as a directional cue to organize the elongation of early muscle fibres. Nature 457: 589-593. 
GUSSONI, E., SONEOKA, Y., STRICKLAND, C.D., BUZNEY, E.A., KHAN, M.K., FLINT, A.F., KUNKEL, L.M. and MULLIGAN, R.C. (1999). Dystrophin expression in the mdx mouse restored by stem cell transplantation. Nature 401: 390-394.

HARTMANN, G., NALDINI, L., WEIDNER, K.M., SACHS, M., VIGNA, E., COMOGLIO, P.M. and BIRCHMEIER, W. (1992). A functional domain in the heavy chain of scatter factor/hepatocyte growth factor binds the c-Met receptor and induces cell dissociation but not mitogenesis. Proc Natl Acad Sci USA 89: 11574-11578.

HASSON, P., DELAURIER, A., BENNETT, M., GRIGORIEVA, E., NAICHE, L.A., PAPAIOANNOU, V.E., MOHUN, T.J. and LOGAN, M.P. (2010). Tbx4 and tbx5 acting in connective tissue are required for limb muscle and tendon patterning. Dev Cell 18: 148-156.

HAUSCHKA, S.D. (1974). Clonal analysis of vertebrate myogenesis. II. Environmental influences upon human muscle differentiation. Dev Biol 37: 329-344.

HAVIS, E., BONNIN, M.A., ESTEVES DE LIMA, J., CHARVET, B., MILET, C. and DUPREZ, D. (2016). TGFbeta and FGF promote tendon progenitor fate and act downstream of muscle contraction to regulate tendon differentiation during chick limb development. Development 143: 3839-3851.

HAYASHI, K. and OZAWA, E. (1995). Myogenic cell migration from somites is induced by tissue contact with medial region of the presumptive limb mesoderm in chick embryos. Development 121: 661-669.

HAZELTON, R.D. (1970). A radioautographic analysis of the migration and fate of cells derived from the occipital somites in the chick embryo with specific reference to the development of the hypoglossal musculature. JEmbryol Exp Morphol24:455-466.

HEYMANN, S., KOUDROVA, M., ARNOLD, H., KOSTER, M. and BRAUN, T. (1996). Regulation and function of SF/HGF during migration of limb muscle precursor cells in chicken. Dev Biol 180: 566-578.

HOUZELSTEIN, D., AUDA-BOUCHER, G., CHERAUD, Y., ROUAUD, T., BLANC, I., TAJBAKHSH, S., BUCKINGHAM, M.E., FONTAINE-PERUS, J. and ROBERT, B. (1999). The homeobox gene Msx 1 is expressed in a subset of somites, and in muscle progenitor cells migrating into the forelimb. Development 126: 2689-2701.

HU, J.K., MCGLINN, E., HARFE, B.D., KARDON, G. and TABIN, C.J. (2012). Autonomous and nonautonomous roles of Hedgehog signaling in regulating limb muscle formation. Genes Dev 26: 2088-2102.

HUANG, A.H. (2017). Coordinated development of the limb musculoskeletal system: Tendon and muscle patterning and integration with the skeleton. Dev Biol. 429: 420-428.

HUANG, R., ZHI, Q., IZPISUA-BELMONTE, J.C., CHRIST, B. and PATEL, K. (1999). Origin and development of the avian tongue muscles. Anat Embryol (Berl) 200: 137-152.

HUANG, R., ZHI, Q., WILTING, J. and CHRIST, B. (1994). The fate of somitocoele cells in avian embryos. Anat Embryol (Berl) 190: 243-250.

HUBAUD, A. and POURQUIE, O. (2014). Signalling dynamics in vertebrate segmentation. Nat Rev Mol Cell Biol 15: 709-721.

IKEYA, M. and TAKADA, S. (1998). Wnt signaling from the dorsal neural tube is required for the formation of the medial dermomyotome. Development 125: 4969-4976.

KAHANE, N., CINNAMON, Y. and KALCHEIM, C. (1998). The cellular mechanism by which the dermomyotome contributes to the second wave of myotome development. Development 125: 4259-4271.

KARDON, G. (1998). Muscle and tendon morphogenesis in the avian hind limb. Development 125: 4019-4032.

KARDON, G., HARFE, B.D. and TABIN, C.J. (2003). A Tcf4-positive mesoderma population provides a prepattern for vertebrate limb muscle patterning. Dev Cell 5: 937-944

KASSAR-DUCHOSSOY, L., GIACONE, E., GAYRAUD-MOREL, B., JORY, A., GOMES, D. and TAJBAKHSH, S. (2005). Pax3/Pax7 mark a novel population of primitive myogenic cells during development. Genes Dev 19: 1426-1431.

KEYNES, R.J. and STERN, C.D. (1984). Segmentation in the vertebrate nervous system. Nature 310: 786-9. KIENY, M. and CHEVALLIER, A. (1979). Autonomy of tendon development in the embryonic chick wing. $J$ Embryol Exp Morphol 49: 153-165.

KOSHER, R.A., SAVAGE, M.P. and WALKER, K.H. (1981). Agradation of hyaluronate accumulation along the proximodistal axis of the embryonic chick limb bud. $J$ Embryol Exp Morphol 63: 85-98.

KRENN, V., BRAND-SABERI, B. and WACHTLER, F. (1991). Hyaluronic acid influences the migration of myoblasts within the avian embryonic wing bud. $A m \mathrm{~J}$ Anat 192: 400-406
KRUCK, S. and SCAAL, M. (2012). Divergent regulation of Wnt-mediated development of the dorsomedial and ventrolateral dermomyotomal lips. Histochem Cell Biol 138: 503-514.

KRUGER, M., MENNERICH, D., FEES, S., SCHAFER, R., MUNDLOS, S. and BRAUN, T. (2001). Sonic hedgehog is a survival factor for hypaxial muscles during mouse development. Development 128: 743-752.

LAI, E.C. (2004). Notch signaling: control of cell communication and cell fate. Development 131: 965-73.

LANCE-JONES, C. (1988). The effect of somite manipulation on the development of motoneuron projection patterns in the embryonic chick hindlimb. Dev Biol 126: 408-419.

LANCE-JONES, C. (1988). The somitic level of origin of embryonic chick hindlimb muscles. Dev Biol 126: 394-407.

LE DOUARIN, N. (1980). Migration and differentiation of neural crest cells. Curr Top Dev Biol 16: 31-85.

LEJARD, V., BLAIS, F., GUERQUIN, M.J., BONNET, A., BONNIN, M.A., HAVIS, E., MALBOUYRES, M., BIDAUD, C.B., MARO, G., GILARDI-HEBENSTREIT, P. et al., (2011). EGR1 and EGR2 involvement in vertebrate tendon differentiation. $J$ Biol Chem 286: 5855-5867.

LINKER, C., LESBROS, C., GROS, J., BURRUS, L.W., RAWLS, A. and MARCELLE, C. (2005). beta-Catenin- dependent Wnt signalling controls the epithelial organisation of somites through the activation of paraxis. Development 132: 3895-3905.

MARCELLE, C., AHLGREN, S. and BRONNER-FRASER, M. (1999). In vivoregulation of somite differentiation and proliferation by Sonic Hedgehog. Dev Biol214:277-287.

MARCELLE, C., LESBROS, C. and LINKER, C. (2002). Somite patterning: a few more pieces of the puzzle. Results Probl Cell Differ 38: 81-108.

MARCELLE, C., STARK, M.R. and BRONNER-FRASER, M. (1997). Coordinate actions of BMPs, Wnts, Shh and noggin mediate patterning of the dorsal somite. Development 124: 3955-3963.

MARICS, I., PADILLA, F., GUILLEMOT, J.F., SCAAL, M. and MARCELLE, C. (2002). FGFR4 signaling is a necessary step in limb muscle differentiation. Development 129: 4559-4569.

MAROTO, M., BONE, R.A. and DALE, J.K. (2012). Somitogenesis. Development 139: 2453-2456. MARTIN, B.L., PEYROT, S.M. and HARLAND, R.M. (2007) Hedgehog signaling regulates the amount of hypaxial muscle development during Xenopus myogenesis. Dev Biol 304: 722-734.

MATHEW, S.J., HANSEN, J.M., MERRELL, A.J., MURPHY, M.M., LAWSON, J.A., HUTCHESON, D.A., HANSEN, M.S., ANGUS-HILL, M. and KARDON, G. (2011). Connective tissue fibroblasts and Tcf4 regulate myogenesis. Development 138 371-384.

MAURO, A. (1961). Satellite cell of skeletal muscle fibers. J Biophys Biochem Cytol 9: 493-495.

MCDERMOTT, A., GUSTAFSSON, M., ELSAM, T., HUI, C.C., EMERSON, C.P., JR. and BORYCKI, A.G. (2005). Gli2 and Gli3 have redundant and context-dependent function in skeletal muscle formation. Development 132: 345-357.

MERRELL, A.J., ELLIS, B.J., FOX, Z.D., LAWSON, J.A., WEISS, J.A. and KARDON, G. (2015). Muscle connective tissue controls development of the diaphragm and is a source of congenital diaphragmatic hernias. Nat Genet 47: 496-504.

MERRELL, A.J. and KARDON, G. (2013). Development of the diaphragm -- a skeletal muscle essential for mammalian respiration. FEBS J 280: 4026-4035.

MITTAPALLI, V.R., HUANG, R., PATEL, K., CHRIST, B. and SCAAL, M. (2005). Arthrotome: a specific joint forming compartment in the avian somite. Dev Dyn 234: 48-53.

MOK, G.F., CARDENAS, R., ANDERTON, H., CAMPBELL, K.H. and SWEETMAN, D. (2014). Interactions between FGF18 and retinoic acid regulate differentiation of chick embryo limb myoblasts. Dev Biol 396: 214-223.

MUNSTERBERG, A.E., KITAJEWSKI, J., BUMCROT, D.A., MCMAHON, A.P. and LASSAR, A.B. (1995). Combinatorial signaling by Sonic hedgehog and Wnt family members induces myogenic bHLH gene expression in the somite. Genes Dev 9: 2911-2922.

MURPHY, M. and KARDON, G. (2011). Origin of vertebrate limb muscle: the role of progenitor and myoblast populations. Curr Top Dev Biol 96: 1-32.

MURRAY, P.D.F. (1928). Chorio-allantoic grafts of the two-day chick, with special reference to the development of the limbs, intestine and skin. Austr. J. Exp. Biol. Med. Sci. 5: 237-256. 
NELSON, W.J. and NUSSE, R. (2004). Convergence of Wnt, beta-catenin, and cadherin pathways. Science 303: 1483-1487.

NODEN, D.M. (1983). The embryonic origins of avian cephalic and cervical muscles and associated connective tissues. Am J Anat 168: 257-276.

OHATA, E., TADOKORO, R., SATO, Y., SAITO, D. and TAKAHASHI, Y. (2009). Notch signal is sufficient to direct an endothelial conversion from non-endothelial somitic cells conveyed to the aortic region by CXCR4. Dev Biol 335: 33-42.

ORDAHL, C.P. and LE DOUARIN, N.M. (1992). Two myogenic lineages within the developing somite. Development 114: 339-353.

PINOT, M. (1970). Le rôle du mésoderme somitique dans la morphogenèse précoce des membres de l'embryon de Poulet J Embryol Exp Morphol 23: 109-151.

POLESSKAYA, A., SEALE, P. and RUDNICKI, M.A. (2003). Wnt signaling induces the myogenic specification of resident CD45+ adult stem cells during muscle regeneration. Cell 113: 841-852.

POUGeT, C., GAUTIER, R., TEILLET, M.A. and JAFFREDO, T. (2006). Somitederived cells replace ventral aortic hemangioblasts and provide aortic smooth muscle cells of the trunk. Development 133: 1013-1022.

POURQUIE, O., FAN, C.M., COLTEY, M., HIRSINGER, E., WATANABE, Y., BREANT, C., FRANCIS-WEST, P., BRICKELL, P., TESSIER-LAVIGNE, M. and LEDOUARIN, N.M. (1996). Lateral and axial signals involved in avian somite patterning: a role for BMP4. Cell 84: 461-471.

REES, E., YOUNG, R.D. and EVANS, D.J. (2003). Spatial and temporal contribution of somitic myoblasts to avian hind limb muscles. Dev Biol 253: 264-278.

RELAIX, F., ROCANCOURT, D., MANSOURI, A. and BUCKINGHAM, M. (2005). A Pax3/Pax7-dependent population of skeletal muscle progenitor cells. Nature 435: 948-953.

RIOS, A.C., SERRALBO, O., SALGADO, D. and MARCELLE, C. (2011). Neural crest regulates myogenesis through the transient activation of NOTCH. Nature 473: 532-535.

SAUNDERS, J.W. (1948). Do the somites contribute to the formation of the chick wing? Anat. Rec. 100: 756. SCAAL, M. (2016). Early development of the vertebral column. Semin Cell Dev Biol 49: 83-91.

SCAAL, M., BONAFEDE, A., DATHE, V., SACHS, M., CANN, G., CHRIST, B. and BRAND-SABERI, B. (1999). SF/HGF is a mediator between limb patterning and muscle development. Development 126: 4885-4893.

SCAAL, M. and CHRIST, B. (2004). Formation and differentiation of the avian dermomyotome. Anat Embryol (Berl) 208: 411-424.

SCHAFER, K. and BRAUN, T. (1999). Early specification of limb muscle precursor cells by the homeobox gene Lbx1h. Nat Genet 23: 213-216.

SCHMIDT, C., STOECKELHUBER, M., MCKINNELL, I., PUTZ, R., CHRIST, B. and PATEL, K. (2004). Wnt 6 regulates the epithelialisation process of the segmental plate mesoderm leading to somite formation. Dev Biol 271: 198-209.

SCHWEISGUTH, F. (2015). Asymmetric cell division in the Drosophila bristle lineage: from the polarization of sensory organ precursor cells to Notch-mediated binary fate decision. Wiley Interdiscip Rev Dev Biol 4: 299-309.

SELLECK, M.A. and STERN, C.D. (1991). Fate mapping and cell lineage analysis of Hensen's node in the chick embryo. Development 112: 615-626.

SERRALBO, O. and MARCELLE, C. (2014). Migrating cells mediate long-range WNT signaling. Development 141: 2057-2063.

SHALABY, F., ROSSANT, J., YAMAGUCHI, T.P., GERTSENSTEIN, M., WU, X.F., BREITMAN, M.L. and SCHUH, A.C. (1995). Failure of blood-island formation and vasculogenesis in Flk-1-deficient mice. Nature 376: 62-66.

SIEIRO, D., RIOS, A.C., HIRST, C.E. and MARCELLE, C. (2016). Cytoplasmic NOTCH and membrane-derived beta-catenin link cell fate choice to epithelial-mesenchymal transition during myogenesis. Elife 5:e14847 (DOI:10.7554/eLife.14847).

STERN, H.M., BROWN, A.M. and HAUSCHKA, S.D. (1995). Myogenesis in paraxial mesoderm: preferential induction by dorsal neural tube and by cells expressing Wnt-1. Development 121: 3675-3686.

SWARTZ, M.E., EBERHART, J., PASQUALE, E.B. and KRULL, C.E. (2001). EphA4/ ephrin-A5 interactions in muscle precursor cell migration in the avian forelimb. Development 128: 4669-4680.

SWINEHART, I.T., SCHLIENTZ, A.J., QUINTANILLA, C.A., MORTLOCK, D.P. and WELLIK, D.M. (2013). Hox11 genes are required for regional patterning and integration of muscle, tendon and bone. Development 140: 4574-4582.

TAJBAKHSH, S., BORELLO, U., VIVARELLI, E., KELLY, R., PAPKOFF, J., DUPREZ, D., BUCKINGHAM, M. and COSSU, G. (1998). Differential activation of Myf5 and MyoD by different Wnts in explants of mouse paraxial mesoderm and the later activation of myogenesis in the absence of Myf5. Development 125: 4155-4162.

TEILLET, M.A., LAPOINTE, F. and LE DOUARIN, N.M. (1998). The relationships between notochord and floor plate in vertebrate development revisited. Proc Natl Acad Sci USA 95: 11733-11738.

TOZER, S., BONNIN, M.A., RELAIX, F., DI SAVINO, S., GARCIA-VILLALBA, P., COUMAILLEAU, P. and DUPREZ, D. (2007). Involvement of vessels and PDGFB in muscle splitting during chick limb development. Development 134: 2579-2591.

TREMBLAY, P., DIETRICH, S., MERICSKAY, M., SCHUBERT, F.R., LI, Z. and PAULIN, D. (1998). A crucial role for Pax3 in the development of the hypaxial musculature and the long-range migration of muscle precursors. Dev Biol 203: 49-61.

VALASEK, P., EVANS, D.J., MAINA, F., GRIM, M. and PATEL, K. (2005). A dual fate of the hindlimb muscle mass: cloacal/perineal musculature develops from leg muscle cells. Development 132: 447-458.

VALASEK, P., THEIS, S., DELAURIER, A., HINITS, Y., LUKE, G.N., OTTO, A.M., MINCHIN, J., HE, L., CHRIST, B., BROOKS, G. etal., (2011). Cellular and molecular investigations into the development of the pectoral girdle. Dev Biol357: 108-116

VASYUTINA, E. and BIRCHMEIER, C. (2006). The development of migrating muscle precursor cells. Anat Embryol (Berl) 211 Suppl 1: 37-41.

VASYUTINA, E., STEBLER, J., BRAND-SABERI, B., SCHULZ, S., RAZ, E. and BIRCHMEIER, C. (2005). CXCR4 and Gab1 cooperate to control the development of migrating muscle progenitor cells. Genes Dev 19: 2187-2198.

VENTERS, S.J. and ORDAHL, C.P. (2002). Persistent myogenic capacity of the dermomyotome dorsomedial lip and restriction of myogenic competence. Development 129: 3873-3885.

WEIDNER, K.M., SACHS, M. and BIRCHMEIER, W. (1993). The Met receptor tyrosine kinase transduces motility, proliferation, and morphogenic signals of scatter factor/ hepatocyte growth factor in epithelial cells. J Cell Biol 121: 145-154.

WILSON-RAWLS, J., HURT, C.R., PARSONS, S.M. and RAWLS, A. (1999). Differential regulation of epaxial and hypaxial muscle development by paraxis. Development 126: 5217-5229.

WILTING, J., EICHMANN, A. and CHRIST, B. (1997). Expression of the avian VEGF receptor homologues Quek1 and Quek2 in blood-vascular and lymphatic endothelial and non-endothelial cells during quail embryonic development. Cell Tissue Res 288: 207-223.

YVERNOGEAU, L., AUDA-BOUCHER, G. and FONTAINE-PERUS, J. (2012). Limb bud colonization by somite- derived angioblasts is a crucial step for myoblast emigration. Development 139: 277-287.

ZHI, Q., HUANG, R., CHRIST, B. and BRAND-SABERI, B. (1996). Participation of individual brachial somites in skeletal muscles of the avian distal wing. Anat Embryol (Berl) 194: 327-339. 


\section{Further Related Reading, published previously in the Int. J. Dev. Biol.}

DYRK2 displays muscle fiber type specific function during zebrafish early somitogenesis

Wei Sun, Shuang Jiao, Xungang Tan, Peijun Zhang and Feng You

Int. J. Dev. Biol. (2017) 61: 459-463

https://doi.org/10.1387/ijdb.160175sj

FoxD1 protein interacts with Wnt and BMP signaling to differentially pattern mesoderm and neural tissue Hanna Polevoy, Anastasia Malyarova, Yuri Fonar, Sara Elias and Dale Frank Int. J. Dev. Biol. (2017) 61: 293-302

https://doi.org/10.1387/ijdb.160300df

Building functional units of movement-generation and movement-sensation in the embryo

Peleg Hasson, Talila Volk and Adi Salzberg

Int. J. Dev. Biol. (2017) 61: 171-178

https://doi.org/10.1387/ijdb.160279as

Models of amphibian myogenesis - the case of Bombina variegata

Leokadia Kie\&lstrok;bówna and Marta Migocka-Patrza\&lstrok;ek

Int. J. Dev. Biol. (2017) 61: 17-27

https://doi.org/10.1387/ijdb.160370mm

SDF-1 controls the muscle and blood vessel formation of the somite

Aisha Abduelmula Ruijin HuangQin Pu, Hirokazu Tamamura, Gabriela Morosan-Puopolo and Beate Brand-Saberi

Int. J. Dev. Biol. (2016) 60: 29-38

https://doi.org/10.1387/ijdb.150132rh

CILP1 is dynamically expressed in the developing musculoskeletal system of the trout Cécile Ralliere, Maxence Fretaud, Violette Thermes and Pierre-Yves Rescan

Int. J. Dev. Biol. (2015) 59: 505-509

https://doi.org/10.1387/ijdb.150136pr

Two-Pore Channel 2 activity is required for slow muscle cell-generated Ca2+ signaling during myogenesis in intact zebrafish

Jeffrey J. Kelu, Hayley L.H. Chan, Sarah E. Webb, Arthur H.H. Cheng, Margarida Ruas, John Parrington, Antony Galione and Andrew L. Miller

Int. J. Dev. Biol. (2015) 59: 313-325

https://doi.org/10.1387/ijdb.150206am

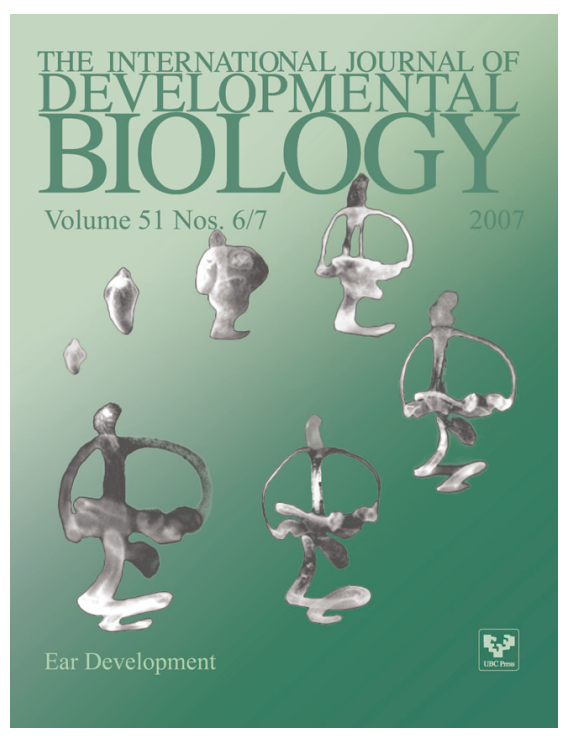

5 yr ISI Impact Factor $(2016)=2.421$
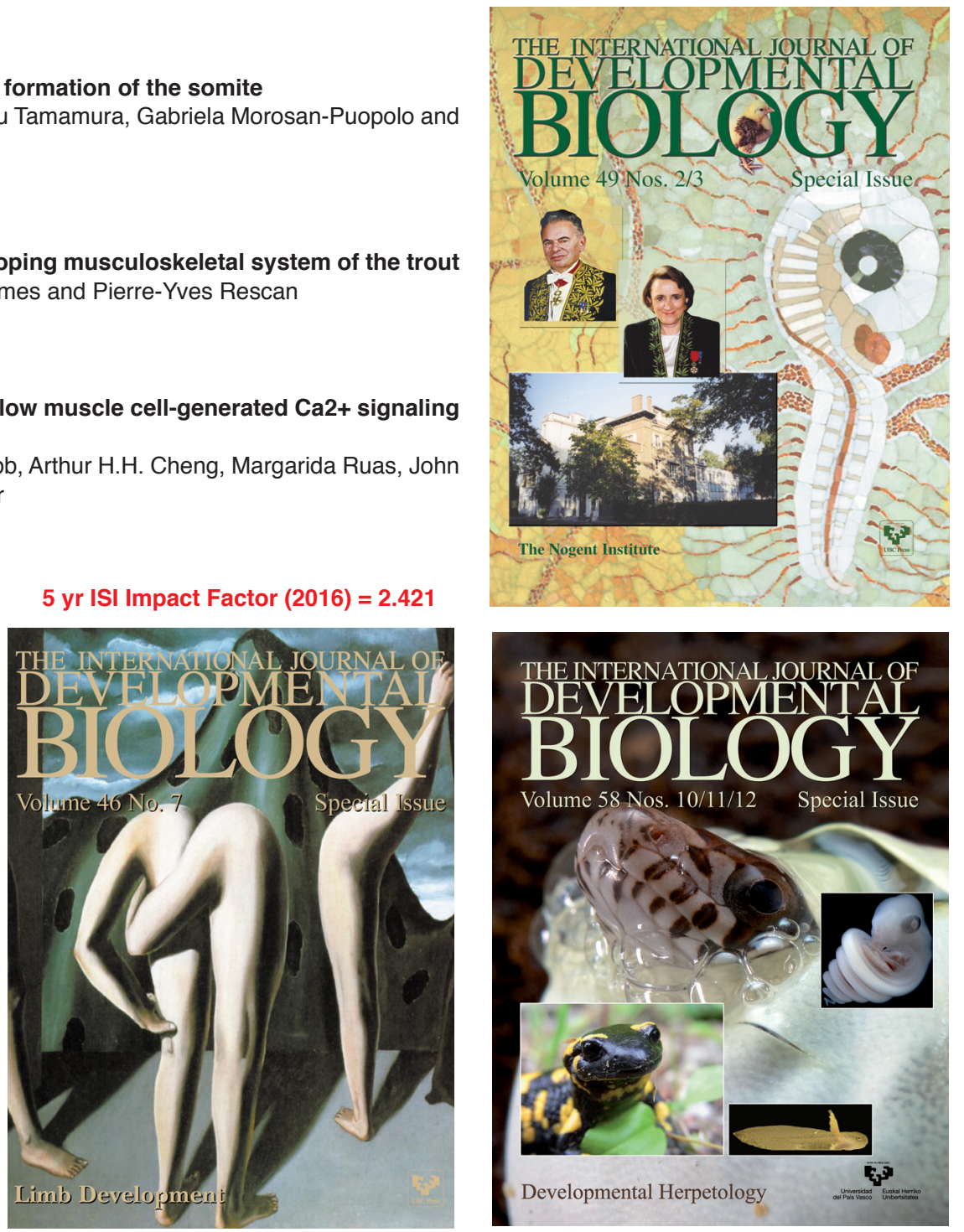